\title{
Comparative study to evaluate the efficacy and safety of oral Mifepristone versus intracervical Dinoprostone gel for induction of labour and their effects on fetomaternal outcome
}

\author{
Anu Pathak ${ }^{1}$, Saroj Singh ${ }^{1}$, Shikha Singh ${ }^{1}$, Rajesh Kumar ${ }^{2}$, Arpita Tyagi ${ }^{1 *}$
}

\author{
${ }^{1}$ Department of Obstetrics and Gynecology, SN Medical College, Agra, Uttar Pradesh, India \\ ${ }^{2}$ Department of Pediatrics, SN Medical College, Agra, Uttar Pradesh, India
}

Received: 12 April 2019

Accepted: 30 May 2019

\author{
*Correspondence: \\ Dr. Arpita Tyagi, \\ E-mail: arpita.tyagi11@gmail.com
}

Copyright: () the author(s), publisher and licensee Medip Academy. This is an open-access article distributed under the terms of the Creative Commons Attribution Non-Commercial License, which permits unrestricted non-commercial use, distribution, and reproduction in any medium, provided the original work is properly cited.

\begin{abstract}
Background: Mifepristone and Dinoprostone are used in inducing labour in pregnancy by acting as cervical ripening drugs. A randomized case control study to evaluate the efficacy, safety and fetomaternal outcome of induction of labour with oral Mifepristone and intracervical Dinoprostone gel was done.

Methods: About 300 patients were included after taking informed consent. 150 patients were placed in each group A and B. In group A patients received $200 \mathrm{mg}$ oral Mifepristone tablet and in group B $0.5 \mathrm{mg}$ Dinoprostone gel was given intracervically and $2^{\text {nd }}$ dose was repeated after 6 hours later if adequate uterine contractions were not achieved. A detailed analysis was carried out in both groups regarding efficacy and safety of drugs in terms of necessity of augmentation of labour with oxytocin, induction to delivery interval, fetal outcome in terms of NICU admission.

Results: $59.33 \%$ cases in Mifepristone group and $72 \%$ case in Dinoprostone group required augmentation with oxytocin. Mean induction delivery interval in Mifepristone group in primigravida was $17.998 \pm 1.128 \mathrm{hrs}$ and mean induction delievery interval in multigravida was $11.648 \pm 1.112$ hours. $88 \%$ cases in mifipristone group and $80 \%$ cases in Dinoprostone group delivered vaginally. NICU admission was $1.33 \%$ in Mifepristone group and $2.66 \%$ in PGE2 gel group.

Conclusions: Mifepristone when compared with intracervical Dinoprostone gel, acts as a better cervical ripening agent and requires lesser need for Oxytocin augmentation. Though, mean induction delivery interval was more with Mifepistone, the incidence of successful vaginal delivery was higher as compared to Dinoprostone.
\end{abstract}

Keywords: Dinoprostone, Induction of labour, Mifepristone, Oxytocin augmentation

\section{INTRODUCTION}

The incidence of labor induction has continued to rise over the past several decades. In developed countries, the number of infants delivered at term following induction of labour can be as high as 1 in 4 delieveries. ${ }^{1-2}$ The WHO Global Survey 2010, on maternal and perinatal health, conducted in 24 countries which included nearly 30000 observations showed that $9.6 \%$ of them were delivered by labour induction. ${ }^{3}$ The survey found that African countries have lower rates of induction of labor (Nigeria 1.4\%) compared with Asian and Latin American countries (highest: Sri Lanka 35.5\%).

Induction can be defined as an intervention intended to artificially initiate uterine contractions resulting in the progressive effacement and dilatation of the cervix which will result in the birth of the baby by vaginal route. 
Induction is indicated when the benefits for the mother and fetus outweigh those of continuing the pregnancy and to achieve vaginal delivery, thus avoiding an unnecessary caesarean section. ${ }^{4}$

Various methods have been used for induction of labour which includes mechanical (amniotomy, balloon-tipped catheters, and natural and synthetic laminaria) and medical methods (include use of prostaglandins, oxytocin and Mifepristone) but an ideal inducing agent must be safe and easy to administer and acceptable to patient.

Mifepristone or RU- 486, an antiprogesterone is a receptor level antagonist, licensed in U.K. in July 1991. Mifepristone, 19-norsteroid has great affinity for the progesterone receptor and thus blocks the action of progesterone at cellular level. As fall in the level of progesterone, is considered one of the important events in the onset of spontaneous labour, it therefore seems that this drug may be useful in labour induction and moreover it also fulfills quality of an ideal inducing agent. ${ }^{5}$

Mifepristione stimulates the release of prostaglandins (PGF2 $\alpha) .{ }^{6}$ Cervical ripening occurs directly or through the blockage of progesterone receptors. Mifepristone stimulates the release of nitric oxide and the expression of inducible nitric oxide synthase in the cervical cells. ${ }^{7}$

Mifepristone and Dinoprostone are used in inducing labour in pregnancy by acting as cervical ripening drugs. Present study was done to compare and portrait the beneficial effects of both the drugs for induction of labour.

\section{METHODS}

A randomized case control study to evaluate the efficacy, safety and fetomaternal outcome of induction of labour with oral Mifepristone and intracervical Dinoprostone gel.

Study population and Place of study- 300 antenatal women attending a North Indian tertiary care hospital. Duration of study: 2 years (July 2016 to July 218).

\section{Inclusion criteria}

- Patient giving consent for the study, singleton pregnancy, cases included were of gestational 35-41 weeks and they had normal latest sonography without any complications.

\section{Exclusion criteria}

- Multiple pregnancies, scarred uterus, fetal distress, any obstetric cause for contraindication for induction of labour, any medical condition that contraindicates use of Mifepristone (adrenal insufficiency, deranged liver and kidney function tests) and Dinoprostone gel (history of asthma) and patients not giving consent for study.

Selected patients were subjected to detailed history; general, systemic and obstetric examination; Modified Bishop's Scoring; routine antenatal blood investigations, urine microscopy, liver and renal function tests; obstetric ultrasonography; Non stress test and the two groups were made:

Group A- Mifepristone group: Patients received 200 mg oral Mifepristone tablet

Group B- Dinoprostone group: $0.5 \mathrm{mg}$ Dinoprostone gel given intracervically and $2^{\text {nd }}$ dose was repeated after 6 hours later if adequate uterine contractions were not achieved

Oxytocin augmentation in both groups was done whenever required.

A detailed analysis was carried out in both groups regarding efficacy and safety of drugs in terms of

\section{Efficacy of drug}

- Improvement in Bishop's score

- Necessity of augmentation of labour with oxytocin

- Induction to delivery interval

\section{Safety of drug}

- Fetal outcomes- Apgar score at $1 \mathrm{~min}$ and $5 \mathrm{~min}$ of birth, need for NICU admissions

- Maternal outcome- any maternal side effect, mode of delivery (normal vaginal/ caesarean), CTG changes

- For monitoring progress of labour: Modified WHO partograph was maintained

- For monitoring fetal condition: continuous CTG monitoring was done

Successful induction was defined as women who entered active labor within 24hours of administration of Mifepristone and Dinoprostone.

Failed induction was defined as women who failed to enter active labor at the end of 24 hours of administration of Mifepristone and maximum dose of Dinoprostone gel.

\section{RESULTS}

Out of 150 Mifepristone group women, 78 (52\%) were primigravida and $82(48 \%)$ were multiparas, whereas out of 150 women in Dinoprostone group $82(54.66 \%)$ were primigravida and $68(45.34 \%)$ were multigravida. The patients were stratified by Bishop Score at entry for further analysis. 
Table 1: Distribution of cases according to patient's demographic profile.

\begin{tabular}{|llll|}
\hline Demographic variables & Mifepristone group & Dinoprostone group & $\mathrm{p}$ value \\
\hline Maternal age in year (Mean $\pm 2 \mathrm{SD})$ & $24.086 \pm 3.327$ years & $24.006 \pm 3.336$ years & $0.83 \mathrm{p}>0.05$ \\
\hline Mean period of gestation (in weeks) & $38.133 \pm 1.314$ weeks & $38.166 \pm 1.323$ weeks & $0.82 \mathrm{p}>0.05$ \\
\hline Mean Bishop' score at time of admission & $4.747 \pm 1.106$ & $4.686 \pm 1.093$ & $0.63 \mathrm{p}>0.05$ \\
\hline
\end{tabular}

Table 2: Need for Oxytocin augmentation.

\begin{tabular}{|lll|}
\hline Need for oxytocin augmentation & Mifepristone group (Group A) & Dinoprostone group (Group B) \\
\hline Not required & $40.66 \%$ & $28 \%$ \\
\hline Required & $59.33 \%$ & $72 \%$ \\
\hline
\end{tabular}

The mean age in Mifepristone group was 24.086 years and in Dinoprostone group mean age was 24.006 years. The mean period of in Mifepristone group was 38.133 weeks and in Dinoprostone group it was 38.166 weeks. The mean scores were 4.747 in Mifepristone and 4.686 in Dinoprostone group respectively. So patients in both groups were comparable in terms of demographic variables.

$59.33 \%$ cases in Mifepristone group and $72 \%$ case in Dinoprostone group required augmentation with oxytocin.

Table 3: Distribution of cases according to induction delivery interval in both groups in primigravida and multigravida.

\begin{tabular}{lllll|}
\hline $\begin{array}{l}\text { Mean induction } \\
\text { delivery interval (in }\end{array}$ & \multicolumn{2}{l}{ Mifepristone Group A } & \multicolumn{2}{l}{ Dinoprostone Group B } \\
\cline { 2 - 3 } & Primigravida & Multigravida & Primigravida & Multigravida \\
hours & $17.998 \pm 1.128$ hours & $11.648 \pm 1.112$ hours & $13.276 \pm 1.216$ hrs & $11.868 \pm 1.106$ hours \\
\hline
\end{tabular}

Table 4: Mode of delivery in both groups.

\begin{tabular}{|lll|}
\hline Mode of delivery & Mifepristone Group A & Dinoprostone Group B \\
\hline Normal vaginal delivery & $88 \%$ & $80 \%$ \\
\hline Caesarean section & $9.33 \%$ & $16 \%$ \\
\hline Instrumental delivery & $2.67 \%$ & $4 \%$ \\
\hline
\end{tabular}

Table 5: Neonatal outcomes in both groups.

\begin{tabular}{|lll|}
\hline Outcomes & Mifepristone Group A & Dinoprostone Group B \\
\hline Mean Apgar score & & \\
\hline At 1 min & $7.10 \pm 1.43$ & $8.20 \pm 1.35$ \\
\hline At 5 min & $7.68 \pm 0.81$ & $8.60 \pm 0.68$ \\
\hline NICU admission & $1.33 \%$ & $2.66 \%$ \\
\hline Neonatal mortality & $0 \%$ & $0 \%$ \\
\hline
\end{tabular}

Mean induction delivery interval in Mifepristone group was 17.998 hours in primigravida and 11.648 hours in multigravida. While induction delivery interval in Dinoprostone group was 13.276 hours in primigravida and 11.868 hours in multigravida.

$88 \%$ patients in Mifepristone group delivered vaginally, $9.33 \%$ had caesarean section due to various reasons. While vaginal delivery rate was $80 \%$ in Dinoprostone group and $16 \%$ patients had caesarean section.
Mean Apgar score at $5 \mathrm{~min}$ in Mifepristone group was 7.68 and 8.60 in Dinoprostone group. NICU admission rate was $1.33 \%$ in Mifepristone group and $2.66 \%$ in Dinoprostone group. No neonatal mortality was seen in Mifepristone group and Dinoprostone group.

Most common indication for caesarean was $5.33 \%$ for non progression of labour in Mifepristone group and fetal distress $(9.33 \%)$ in Dinoprostone group. (No significant maternal complication was noted in both groups). 
Table 6: Maternal outcomes in both groups.

\begin{tabular}{|c|c|c|}
\hline Outcomes & $\begin{array}{l}\text { Mifepristone } \\
\text { Group A }\end{array}$ & $\begin{array}{l}\text { Dinoprostone } \\
\text { Group B }\end{array}$ \\
\hline $\begin{array}{l}\text { Caesarean section } \\
\text { rates }\end{array}$ & $9.33 \%$ & $16 \%$ \\
\hline \multicolumn{3}{|c|}{ Indication of caesarean } \\
\hline Fetal distress & $2.66 \%$ & $9.33 \%$ \\
\hline NPOL & $5.33 \%$ & $4 \%$ \\
\hline Persistant ROP & $1.33 \%$ & $2.66 \%$ \\
\hline \multicolumn{3}{|c|}{ Maternal complications } \\
\hline GI symptoms & $0.66 \%$ & $3 \%$ \\
\hline $\begin{array}{l}\text { Uterine } \\
\text { hyperstimulation }\end{array}$ & Nil & Nil \\
\hline
\end{tabular}

\section{DISCUSSION}

In this study Table 1 shows that demographic variables like age, parity, period of gestation and Bishop' score at the time of induction was comparable in both groups.

According to Table 2, it was seen that $59.33 \%$ cases in Mifepristone group and $72 \%$ case in Dinoprostone group required augmentation with oxytocin. This difference was because of different properties of the two agents used. Dinoprostone is having mainly cervical ripening property so it needs oxytocin for augmentation of labour. But on statistically analyzing the data it was found that it was not significant. In the study by Vidya Gaikwad et al, $868.1 \%$ patients required augmentation of labour and $31.9 \%$ did not require augmentation of labour with oxytocin. ${ }^{8}$ In study by Sailatha $\mathrm{R}$ et al, it was found that requirement of oxytocin on augmentation was less with Mifepristone (24\%) when compared to Dinoprostone (38\%). ${ }^{9}$ Difference was not statistically significant(p value 0.130$)$.

According to Table 3 in this study, the mean induction delivery interval in Mifepristone group in primigravida was $17.998 \pm 1.128$ hours and mean induction delivery interval in multigravida was $11.648 \pm 1.112$ hours which is comparatively less than the the randomized controlled trial conducted by Yelikar et al, in which mean induction delivery interval was $1907 \pm 368.4 \mathrm{~min} .{ }^{10}$ This difference was attributed to difference in mean Bishop's score at the time of induction which was 4.746 \pm 1.106 in Mifepristone group in this study and $2.02 \pm 0.749$ in study by Yelikar et al.

According to Table 4, in this study $88 \%$ cases in mifipristone group and $80 \%$ cases in Dinoprostone group delivered vaginally and it was consistent with rate of vaginal delivery in studies by Gaikwad $\mathrm{V}$ et al, in which $84 \%$ cases in Mifepristone group and 56\% cases in Dinoprostone group deliverd vaginally. Caesarean rates were less in Mifepristone group.

Table 5 and Table 6 shows comparison of Mifepristone and Dinoprostone on basis of various parameters affecting fetal and maternal outcomes. In this study
2.66\% cases in Mifepristone group and $9.33 \%$ cases in Dinoprostone group had caesarean section for fetal distress. In study by Gaikwad V et al, $8 \%$ cases in Mifepristone group and 10\% cases in Dinoprostone group had caesarean section for fetal distress. This shows Mifepristone does not increase risk of fetal distress.

In our study, NICU admission was $1.33 \%$ in Mifepristone group and $2.66 \%$ in PGE2 gel group. There was no neonatal mortality in both group. In this aspect, our study is consistent with study conducted by Wing DA et al, in which no statistically significant difference in neonatal outcome between Mifepristone treated group and control group. ${ }^{11}$ Our study is also comparable with Kanan Yelikar study in which there was no statistically significant difference in perinatal outcomes between two groups. Mean Apgar score at $5 \mathrm{~min}$ in Mifepristone group was 8.20 and 8.60 in Dinoprostone group. In the study by Sailatha R et al, mean Apgar score in Mifepristone group and Dinoprostone group at $5 \mathrm{~min}$ was $9.04 \pm 0.41$ and $8.9 \pm 0.42$ respectively.

\section{CONCLUSION}

Mifepristone when compared with intracervical Dinoprostone gel, acts as a better cervical ripening agent and requires lesser need for Oxytocin augmentation. Main advantage of Mifepristone is that it can be given on outpatient basis and the patient is asked to report with initiation of labour. Whereas with Dinoprostone, patient must be hospitalized and skilled person is required for instillation of gel. Though, mean induction delivery interval was more with Mifepistone, the incidence of successful vaginal delivery was higher as compared to Dinoprostone.

Mifepristone and Dinoprostone are comparable in terms of fetomaternal outcome. Mifepristone can be safe alternate to Dinoprostone in induction of labour, especially when prostaglandins are contraindicated. Mifepristone combined with or without oxytocin augmentation is a safe, efficient, economical and convenient inducing agent for initiation of labor in women at term. Thus Mifepristone is a safe and effective labour inducing agent. It can improve the outcome of labour induction in terms of increased vaginal delivery rates with no adverse fetomaternal outcomes. However, further trials with bigger sample size are required.

Funding: No funding sources

Conflict of interest: None declared

Ethical approval: The study was approved by the Institutional Ethics Committee

\section{REFERENCES}

1. Caughey AB. Maternal and neonatal outcomes of elective induction of labour. Evid Rep Technol Assess. 2009;176:1-257. 
2. Declercq Eugene R. Listening to mothers II: Report of the Second National US Survey of Women's Childbearing Experiences: Conducted JanuaryFebruary 2006 for childbirth Connection by Harris Interactive(R) in partnership with Lamaze International. J Perinatal Edu. 2007;16(4):9-14.

3. WHO Global Survey on Maternal and Perinatal Health. Induction of labour data. Geneva, WHO, 2010. Available at: http://www.who.int/reproductive health/topics/best_pravtices/global_survey.

4. Gary Cunnigham F, Leveno KJ, Bloom SL, Hauth JC, Williams LC. Obstetrics $22^{\text {nd }}$ Edition, Gilstrap III, kotharine D. Wenstrom, Section II - Chapter 6 Parturition. - 168, Section IV - Chapter 22 Induction. Of labour - 536.

5. Speroff L, Fritz MA. Clinical gynecologic endocrinology and infertility. lippincott Williams \& wilkins; 2005.

6. Berthois Y, Salat-Baroux J, Cornet, D, De Brux J, Kopp F, Martin PM. A multiparametric analysis of endometrial estrogen and progesterone receptors after the postovulatory administration of Mifepristone. Fertil Steril. 1991;55(3):547-54.

7. Tommiska MV, Butzow R, Ylikorkala O, Mikkola TS. Mifepristone induced Nitric oxide release and expression of nitric oxide synthases in human cervix. Human Repro. 2006;21(8):2180-4.

8. Vidya G, Bilsi M, Mangalpuri. Comparative analysis of safety, Efficacy and fetomaternal outcome of induction of labour with Mifepristone versus intracervical Dinoprostone gel. RJPBS. 2014;5(2):611

9. Sailatha R, Famida AM, Chellaiyan VG, Vijayalakshmi K, Sathiya S, Renuka S. Mifepristone: an alternate to dinoprostone in induction of labour. Int J Repro Contracep Obs Gynecol. 2017;6(5):1881.

10. Yelikar K, Deshpande S, Deshpande R, Lone D. Safety and efficacy of oral mifepristone in preinduction cervical ripening and induction of labour in prolonged pregnancy. J Obs Gynecol India. 2015;65(4):221-5.

11. Wing DA, Guberman C, Fassett M. A randomized comparison of oral Mifepristone to intravenous oxytocin for labour induction in women with prelabour rupture of membranes beyond 36 weeks gestation. Am J Obstet Gynecol. 2005;192(2):44551.

Cite this article as: Pathak A, Singh S, Singh S, Kumar R, Tyagi A. Comparative study to evaluate the efficacy and safety of oral Mifepristone versus intracervical Dinoprostone gel for induction of labour and their effects on fetomaternal outcome. Int $\mathrm{J}$ Reprod Contracept Obstet Gynecol 2019;8:2678-82. 